\title{
Health risk assessment of heavy metals in roadside soil along the Hemmat Highway of Tehran, Iran, in 2014
}

\author{
Movafagh A, $\mathrm{MSc}^{1}$, Mansouri N, $\mathrm{PhD}^{2 *}$, Moattar F, $\mathrm{PhD}^{3}$, Vafaeinejad $\mathrm{AR}^{4}$ \\ 1- Student of PhD, Dept. of Environmental and Energy, Science and Research Branch, Islamic Azad University, Tehran, \\ Iran. 2- Associate Prof, Dept. of Environmental and Energy, Science and Research Branch, Islamic Azad University, Tehran, \\ Iran. 3- professor., Dept. of Environmental and Energy, Science and Research Branch, Islamic Azad University, Tehran. \\ Iran. 4- Assistant Prof, Dept. of Remote Sensing and GIS, Science and Research Branch, Islamic Azad University, Tehran, \\ Iran.
}

\begin{abstract}
Received: July 2016, Accepted: October 2016

Background: The present study investigated the impact of land use on health risks (cancerous and non-cancerous) of heavy metals in soil along the Hemmat Highway of Tehran, Iran.

Materials and Methods: A total of 28 soil samples were collected in August 2014 from the roadside soil of the Hemmat Highway. The collected samples were air-dried and digested, and then, analyzed for heavy metals using an atomic absorption spectrophotometer (AAS). Non-carcinogenic and carcinogenic health risks were calculated for different land uses (green space, residential area, under construction, and natural) along the Hemmat Highway.

Results: The hazard index ( $\mathrm{HI})$ of $\mathrm{Pb}, \mathrm{Zn}, \mathrm{Cd}, \mathrm{Cr}$, and $\mathrm{Ni}$ was, respectively, $0.28,0.19 \times 10^{-2}, 0.032$, $0.043,0.006$ for children, and was $0.037,0.24 \times 10^{-3}, 0.014,0.012,0.76 \times 10^{-3}$ for adults. Carcinogenic risk of metals was analyzed for $\mathrm{Cd}, \mathrm{Cr}$, and $\mathrm{Ni}$. The carcinogenic risk of $\mathrm{Pb}, \mathrm{Ni}, \mathrm{Zn}$, and Cd was $0.144 \times 10^{-7}, 0.427 \times 10^{-6}$, and $9.41 \times 10^{-2}$, respectively.

Conclusions: The carcinogenic risk levels of the three studied metals were $<10^{-6}$ with higher values attributed to Cr. HIs for all metals were lower than their threshold values, indicating nil health hazards. The results of risk assessment showed that the highest risk value was related to ingestion of $\mathrm{Pb}$.
\end{abstract}

Keywords: Health Risk, Land, Soil, Heavy Metal

\section{Introduction}

Heavy metals have toxic, non-biodegradable, and accumulative properties, due to which they could have potentially adverse health effects on inhabitants. They may cause DNA damage, and may induce mutagenic, teratogenic, and carcinogenic effects (1). For instance, the excessive intake of $\mathrm{Pb}$ can damage the nervous, skeletal, circulatory, enzymatic, endocrine, and immune systems (2). The chronic effects of $\mathrm{Cr}$ and $\mathrm{Cd}$ dust or aerosol articulate matter intake through soil ingestion consist of lung cancer, pulmonary adenocarcinomas, prostatic proliferative lesions, bone fractures, kidney dysfunction, and hypertension (2). $\mathrm{Cu}$ and $\mathrm{Zn}$ can change the function of the human central nervous system and respiratory system, and disrupt the endocrine system (3).

There is also evidence that chronic exposure to low doses of carcinogenic heavy metals may cause many types of cancer (4). Thus, heavy metals are important issue in the environment. Both natural (weathering, erosion of parent rocks, atmospheric deposition, volcanic activities, and etc.) and anthropogenic (sewage irrigation, the addition of manures, fertilizers and pesticides, domestic waste, industries and transportation, etc.) activities cause soil contamination by heavy metals (5-7).

\footnotetext{
* Corresponding author: Nabiollah Mansouri, Dept. of Environmental and Energy, Science and Research Branch, Islamic Azad University, Tehran, Iran Email: nmansourin@yahoo.com
} 
The most common heavy metals released by vehicles on roads are cadmium (Cd), chromium $(\mathrm{Cr})$, lead $(\mathrm{Pb})$, nickel $(\mathrm{Ni})$, and zinc (Zn) (8); thus, we studied these metals.

Pollutants enter the human body through respiration, inhalation, and direct skin contact causing negative health effects (2,9-10), especially in children, due to their underdeveloped immune systems and inadvertent ingestion of much dust through the hand-to-mouth pathway $(3,11)$. It is estimated that $50-200 \mathrm{mg} /$ day soil could be ingested by children (1).

Young children are particularly sensitive to heavy metal poisoning, because childhood is the period of maximal brain and body growth (8). Therefore, it is important to assess the health risk of toxic metals in the environment. Metal levels of roadside dust are usually higher than other media (e.g., soils), and roadside dust can be re-suspended frequently; thus, individuals bicycling or walking on the roadside could easily be exposed to the toxicants in the dust (1). Therefore, dust samples were studied in the present study.

Roadside dust particles in urban regions have a high surface area and are easily transported and deposited, and carry a potentially toxic element load (8).

Tehran (the capital of Iran) is rated as one of the world's most polluted cities wherein, with rapid urbanization, industrialization, and population growth during the last two decades, the heavy metal pollution in urban soil and roadside dust has turned into a serious issue (12).

While numerous studies of heavy metal contamination via roadside soil have been carried out in developed countries (13), only limited information is available in this regard in developing countries. For example, Junhua et al. found that the hazard index (HI) for all metals were lower than their threshold values, indicating the lack of health hazards in Maha Sarakham, Thailand (3).

Olawoyin et al. showed that mean concentrations $(0-15 \mathrm{~cm})$ of $\mathrm{Zn}(58.3 \pm 37.0)$, $\mathrm{Cd}(1.3 \pm 1.0), \mathrm{Cr}(\mathrm{VI})(13.2 \pm 5.5), \mathrm{Pb}(895.1$ \pm 423.9), and $\mathrm{Ni}(42.7 \pm 20.3)$ were higher than some guidelines and standard values. The risk assessment with the use of United States Environmental Protection Agency (EPA) models showed that metals with the highest cancer risk values $(\mathrm{Pb}=2.62 \mathrm{E}-02$ and $\mathrm{Cr}(\mathrm{VI})$ $=1.52 \mathrm{E}-02$ ) have the potential of affecting the health status, especially of children in the Niger USA (14).

$\mathrm{Wu}$ et al. measured the concentrations of As, $\mathrm{Cd}, \mathrm{Co}, \mathrm{Cr}, \mathrm{Cu}, \mathrm{Hg}, \mathrm{Mn}, \mathrm{Ni}, \mathrm{Pb}, \mathrm{V}$, and $\mathrm{Zn}$ in the soil in Dongguan, China (9). The mean concentrations were lower than both the soil environmental quality standards of China and the Canadian soil quality guidelines. Risk assessment was performed using the Department of Energy (DoE) model. They reported that the element of As may pose both carcinogenic and non-carcinogenic risks to human health. They also showed that the main exposure pathways of As to the human body are ingestion and inhalation of soil particles (9).

In Iran, Saeedi et al. reported that traffic and related activities, and petrogenic and pyrogenic sources could be the main anthropogenic sources of heavy metals and polycyclic aromatic hydrocarbons (PAHs) in street dust in Tehran (15). Keshavarzi et al. performed human health risk assessment, and studied chemical speciation and pollution level of selected heavy metals in urban street dust in Shiraz (Iran) (12). They showed that carcinogenic risk and non-carcinogenic risk due to urban street dust exposure is acceptable in Shiraz. Gholampour et al. investigated the exposure and health impacts of outdoor particulate matter (PM) in both urban and industrialized areas of Tabriz (16). According to the cardiovascular and respiratory mortalities associated with Total Suspended Particles TSP and $\mathrm{PM}_{10}$.

Numerous researches have been carried out on heavy metals contamination; distribution and source identification of street dust have been carried out in innumerable cities. However, there is no information available on potentially toxic metals in surface dust of Tehran city. 
Hemmat is one of the relatively new and heavily traveled highways of Tehran and few environmental studies have been conducted on it. For this reason, the Hemmat highway was selected as the study area in this study.

The main aim of this study was to evaluate the concentration and health risk of $\mathrm{Cd}, \mathrm{Cr}, \mathrm{Ni}, \mathrm{Pb}$, and $\mathrm{Zn}$ in roadside soil from Hemmat Highway of Tehran according to distance from edge of the road and land use in the study area.

Table 1: Exact location of sampling stations

\begin{tabular}{|c|c|c|c|c|}
\hline Sample & $\mathbf{N}$ & $\mathbf{E}$ & $\begin{array}{l}\text { Distance from edge of the road } \\
(\mathbf{m})\end{array}$ & Land use in the study area \\
\hline 1 & $35^{\circ} 45.655$ & $051^{\circ} 14.858$ & $0-10$ & Green space \\
\hline 2 & $35^{\circ} 45.650$ & $051^{\circ} 14.858$ & $10-20$ & Green space \\
\hline 3 & $35^{\circ} 45.468$ & $051^{\circ} 13.830^{\prime}$ & $0-10$ & Residential \\
\hline 4 & $35^{\circ} 45.487$ & $051^{\circ} 13.816$ & $10-20$ & Residential \\
\hline 5 & $35^{\circ} 45.421$ & $051^{\circ} 13.248$ & $0-10$ & Under construction \\
\hline 6 & $35^{\circ} 45.415$ & $051^{\circ} 13.251$ & $10-20$ & Under construction \\
\hline 7 & $35^{\circ} 45.507$ & $051^{\circ} 12.346$ & $0-10$ & Green space \\
\hline 8 & $35^{\circ} 45.510$ & $051^{\circ} 12.360$ & $10-20$ & Green space \\
\hline 9 & $35^{\circ} 45.472$ & $051^{\circ} 11.826$ & $0-10$ & Under construction \\
\hline 10 & $35^{\circ} 45.479$ & $051^{\circ} 11.826^{\prime}$ & $10-20$ & Under construction \\
\hline 11 & $35^{\circ} 45.361$ & $051^{\circ} 11.313$ & $0-10$ & Natural \\
\hline 12 & $35^{\circ} 45.369$ & $051^{\circ} 11.316$ & $10-20$ & Natural \\
\hline 13 & $35^{\circ} 45.702$ & $051^{\circ} 10.041^{\prime}$ & $0-10$ & Natural \\
\hline 14 & $35^{\circ} 45.479$ & $051^{\circ} 11.826^{\prime}$ & $10-20$ & Natural \\
\hline 15 & $35^{\circ} 45.531$ & $051^{\circ} 10.408$ & $0-10$ & Natural \\
\hline 16 & $35^{\circ} 45.541$ & $051^{\circ} 10.406^{\prime}$ & $10-20$ & Natural \\
\hline 17 & $35^{\circ} 45.361$ & $051^{\circ} 11.313$ & $0-10$ & Under construction \\
\hline 18 & $35^{\circ} 45.369$ & $051^{\circ} 11.316$ & $10-20$ & Under construction \\
\hline 19 & $35^{\circ} 45.472$ & $051^{\circ} 11.826^{\prime}$ & $0-10$ & Residential \\
\hline 20 & $35^{\circ} 45.479$ & $051^{\circ} 11.826$ & $10-20$ & Residential \\
\hline 21 & $35^{\circ} 45.507$ & $051^{\circ} 12.346$ & $0-10$ & Green space \\
\hline 22 & $35^{\circ} 45.510$ & $051^{\circ} 12.360$ & $10-20$ & Green space \\
\hline 23 & $35^{\circ} 45.421$ & $051^{\circ} 13.248$ & $0-10$ & Under construction \\
\hline 24 & $35^{\circ} 45.415$ & $051^{\circ} 13.251$ & $10-20$ & Under construction \\
\hline 25 & $35^{\circ} 45.468$ & $051^{\circ} 13.830$ & $0-10$ & Green space \\
\hline 26 & $35^{\circ} 45.487$ & $051^{\circ} 13.816$ & $10-20$ & Green space \\
\hline 27 & $35^{\circ} 45.655$ & $051^{\circ} 14.858$ & $0-10$ & Residential \\
\hline 28 & $35^{\circ} 45.650$ & $051^{\circ} 14.858$ & $10-20$ & Residential \\
\hline
\end{tabular}

\section{Material and Methods}

Sampling was conducted from the East to West and West to East of Hemmat Highway (round trip) from the intersection of Azadegan Boulevard and Hemmat Highway by Pazhohesh Boulevard.

The samples were collected at the distance length of $14 \mathrm{~km}$ from the highway. The distance between sampling stations was $1 \mathrm{~km}$.

At each station, samples were collected at two distances of 0-10 and 10-20 m from the edge of the highway. Efforts were made to collect samples from surface soil $(0-10 \mathrm{~cm})$ and avoid other sources of contamination at each site. The area surrounding the highway has different land uses, including green space, construction, residential, and natural land uses (Figure 1). In case of heavy rainfall, strong storm, and waste discharge in the sample stations, they were excluded from the study.

A total of 28 soil samples were collected in August 2014 from roadside soil of Hemmat Highway. Details of the exact locations of sampling stations are presented in table 1.

Approximately $600 \mathrm{~g}$ per sample of roadside soil was collected with stainless steel scoops 
from $0-5 \mathrm{~cm}$ of ground surface, and then, placed into polyethylene bags for transportation to the laboratory. According to the EPA, stainless steel scoops are suitable because they do not contaminate soil samples with the metals used in the construction of the samples (17).

The collected samples were air-dried at room temperature, ground, and sieved through a 230 mesh nylon sieve. For the total heavy metal content analysis, $600 \mathrm{mg}$ of each dried sample was digested by $\mathrm{HClO}_{4}, \mathrm{HCl}, \mathrm{HNO}_{3}$, and $\mathrm{HF}$ (Merck \& Co., USA) (18). The solutions of digested samples were analyzed for $\mathrm{Cd}, \mathrm{Ni}$, $\mathrm{Pb}, \mathrm{Cu}, \mathrm{Zn}$, and $\mathrm{Cr}$ using an atomic absorption spectrophotometer (AA-700 series, Shimadzu Corp., Japan) flame mode. The detection limits of the spectrometer were $0.0150 \mathrm{mg} / \mathrm{ml}$ for $\mathrm{Cd}$, $0.1250 \mathrm{mg} / \mathrm{ml}$ for $\mathrm{Pb}, 0.0075 \mathrm{mg} / \mathrm{ml}$ for $\mathrm{Zn}$, and $0.0500 \mathrm{mg} / \mathrm{ml}$ for $\mathrm{Ni}$.

Different models are available for human health risk assessment of heavy metals in soil which are presented below.

\section{1) World Health Organization Model}

The approach proposed by the World Health Organization (WHO) was applied using the AirQ software (version 2.2.3, WHO European Centre for Environment and Health, Bilthoven Division, Netherlands) (12).

\section{2) Department of Energy Model (19)}

In this model, three ways of human body exposure to heavy metals were considered; (a) direct oral ingestion of soil particles (CDIing), (b) dermal absorption of elements (CDIdermal), and (c) inhalation of resuspended soil particulates through the nose or mouth (CDIinh).

3) United States Environmental Protection
Agency Model

This Model is similar to the DoE Model (20). In the EPA model, the exposure dose was calculated for children and adults.

The model used in this study to calculate the human exposure to roadside dust metals is based on that developed by the EPA.

Health risk assessment model: The EPA model is based on five assumptions (21). The first assumption is that human beings are exposed to roadside dust through the three main pathways of ingestion of dust particles, inhalation of dust particles, and dermal contact with dust particles. The second was that intake rates and particle emission can be approximated by those developed for soil. The third was that some exposure parameters of residents of the observed areas are similar to those of reference populations. The fourth was that total non-carcinogenic risk could be calculated for each metal $(\mathrm{Pb}, \mathrm{Cr}, \mathrm{Zn}, \mathrm{Cd}$, and $\mathrm{Ni}$ ) by summing the individual risks of the three exposure ways. The fifth assumption was that total carcinogenic risk could be computed for each metal (As, Cd, and $\mathrm{Cr}$ ) by summing the individual risks calculated for the three exposure ways.

The equations provide by the EPA for calculating exposure amounts of potentially toxic metals through the three routes are listed below (20). The dose received via each of the three paths was calculated using the following Equations (20):

$$
\begin{aligned}
& D_{\text {inh }}=\frac{C \times I n h R \times E F \times E D}{P E F \times B W \times A T}, D_{\text {ing }}=\frac{C \times I n g R \times E F \times E D}{B W \times A T} \times 10^{-6}, D_{\text {dermal }}=\frac{C \times S L \times S A \times A B S \times E F \times E D}{B W \times A T} \times 10^{-6} \\
& L A D D=\frac{C \times E F}{A T \times P E F} \times\left(\frac{I n h R_{\text {child }} \times E D_{\text {child }}}{B W_{\text {child }}}+\frac{I n h R_{\text {adult }} \times E D_{\text {adult }}}{B W_{\text {adult }}}\right)
\end{aligned}
$$

Where $D_{\text {ing }}$ is the daily dose of hand-to-mouth ingestion of substrate particles, $D_{\text {inh }}$ is the daily dose of inhalation of re-suspended particles through the mouth and nose, $D_{\text {dermal }}$ is the daily 
dose of dermal absorption of trace elements in particles adhered to exposed skin, LADD is the lifetime average daily dose for carcinogenic elements through inhalation. The meaning and corresponding unit values of other parameters are provided in table 2 .

Table 2: Meaning and corresponding unit values of parameters

\begin{tabular}{clcc}
\hline \multirow{2}{*}{ Parameter } & \multicolumn{1}{c}{ Meaning (unit values) } & Child & Aalues \\
\cline { 3 - 4 } & & - & Adult \\
\hline C & Exposure-point concentration $(\mathrm{mg} / \mathrm{kg})$ & 200 & - \\
\hline IngR & Ingestion rate $(\mathrm{mg} /$ day) & 7.6 & 100 \\
\hline InhR & Inhalation rate $\left(\mathrm{m}^{3} / \mathrm{day}\right)$ & $1.36 \times 10^{9}$ & $1.36 \times 10^{9}$ \\
\hline PEF & Particle emission factor $\left(\mathrm{m}^{3} / \mathrm{kg}\right)$ & 2800 & 5700 \\
\hline SA & Exposed skin area $\left(\mathrm{cm}^{2}\right)$ & 0.2 & 0.7 \\
\hline SL & Skin adherence factor $\left[\mathrm{mg} /\left(\mathrm{cm}^{2}\right.\right.$ hour) & 0.001 & 0.001 \\
\hline ABS & Dermal absorpton factor $($ unitless) & 6 & 24 \\
\hline ED & Exposure duration $($ year) & 180 & 180 \\
\hline EF & Exposure frequency $($ day/year) & 15 & 70 \\
\hline BW & Average body weight $(\mathrm{kg})$ & ED $\times 365$ (for non-carcinogens) \\
\hline AT & Average time (day) & $70 \times 365$ (for carcinogens)
\end{tabular}

The non-carcinogenic risks for individual metals were calculated using the following equation:

$$
H I=\sum H Q, H Q=D / R f d
$$

where $\mathrm{HI}$ is the hazard index, HQ is the hazard quotient, $\mathrm{D}$ is average daily dose calculated for each element and exposure pathway, and Rfd is specific reference dose given for each pollutant parameter. The particular reference dose ( $\mathrm{Rfd})(\mathrm{mg} / \mathrm{kg}$.day) was an estimate of maximum permissible risk of a human population through daily exposure during a lifetime. If $\mathrm{HQ}$ or $\mathrm{HI}$ exceeds 1 , there is a chance of occurrence of non-carcinogenic effects, with a probability which tends to increase as the value of $\mathrm{HQ}$ or $\mathrm{HI}$ increases (20).
The potential was calculated using the following equation:

$\mathrm{CR}=\mathrm{D} \times \mathrm{SF}$

where SF is the corresponding slope factor.

According to the EPA, if the value of CR is above $10^{-4}-10^{-6}$, the exposed population is at risk.

\section{Results}

\section{Concentrations of heavy metals in roadside} soil

The concentrations of heavy metals in roadside soil are shown in table 3 .

The mean $\mathrm{Pb}, \mathrm{Cr}, \mathrm{Ni}, \mathrm{Zn}$, and $\mathrm{Cd}$ concentrations were $144 \pm 89.90,17.20 \pm 9.02$, $18.91 \pm 6.62,86.84 \pm 46.72$, and $3.86 \pm 2.02$ $\mathrm{mg} / \mathrm{kg}$, respectively.

Table 3: Concentrations of heavy metals $(\mathrm{mg} / \mathrm{kg})$ in roadside soil

\begin{tabular}{cccc}
\hline Heavy metals & Minimum & Maximum & Mean \\
\hline $\mathbf{P b}$ & 53.58 & 370.38 & 144 \\
\hline $\mathbf{C r}$ & 10.39 & 45.90 & 17.20 \\
\hline $\mathbf{N i}$ & 10.50 & 28.13 & 18.91 \\
\hline $\mathbf{Z n}$ & 12.99 & 173.74 & 86.84 \\
\hline $\mathbf{C d}$ & 0.44 & 7.94 & 3.86 \\
\hline
\end{tabular}

Health risk assessment of heavy metals

The results of health risk assessment are shown in table 4. As is depicted, non- carcinogenic health risks for children were higher than adults.

Health risk assessment of heavy metals in different land uses 
The non-carcinogenic risk was also calculated for different land uses and both adults and children, and the corresponding results are presented in tables 5-8.

\section{Green space}

As denoted in table 5, the non-carcinogenic health risk for children was higher than adults.

Table 4: Exposure dose, hazard quotient, and risk for each element and exposure pathway (mg/kg.day)

\begin{tabular}{|c|c|c|c|c|c|}
\hline & $\mathbf{P b}$ & Zn & Cd & $\mathrm{Cr}$ & $\mathbf{N i}$ \\
\hline RfDing $_{\text {in }}$ & $3.50 \times 10^{-03}$ & 0.30 & 0.001 & 0.003 & 0.02 \\
\hline RfDinh $_{\text {in }}$ & $3.50 \times 10^{-02}$ & 0.30 & 0.001 & $0.286 \times 10^{-4}$ & 0.02 \\
\hline RfDd $\times 10 \mathrm{rmal}$ & $5.25 \times 10^{-04}$ & 0.06 & $0.1 \times 10^{-4}$ & $0.06-3$ & $0.54 \times 10$ \\
\hline Sfinh $_{\text {inh }}$ & & & 6.30 & 42 & 0.84 \\
\hline \multicolumn{6}{|l|}{ Child } \\
\hline Ding & $0.95 \times 10^{-3}$ & $0.57 \times 10^{-3}$ & $2.54 \times 10^{-5}$ & $0.11 \times 10^{-3}$ & $0.12 \times 10^{-3}$ \\
\hline $\mathbf{D}_{\text {inh }}$ & $2.65 \times 10^{-8}$ & $0.16 \times 10^{-9}$ & $7.09 \times 10^{-10}$ & $3.16 \times 10^{-9}$ & $3.47 \times 10^{-9}$ \\
\hline D dermal & $2.65 \times 10^{-6}$ & $0.16 \times 10^{-7}$ & $7.11 \times 10^{-8}$ & $3.17 \times 10^{-7}$ & $3.48 \times 10^{-7}$ \\
\hline LADD & & & $2.29 \times 10^{-9}$ & $10.17 \times 10^{-9}$ & $11.2 \times 10^{-9}$ \\
\hline $\mathrm{HQ}_{\text {ing }}$ & 0.27 & 0.04 & 0.006 & 0.002 & 0.025 \\
\hline HQ $_{\text {inh }}$ & $7.59 \times 10^{-7}$ & $5.32 \times 10^{-8}$ & $7.09 \times 10^{-7}$ & $0.11 \times 10^{-3}$ & $1.74 \times 10^{-7}$ \\
\hline HQ dermal & 0.005 & $2.67 \times 10^{-5}$ & 0.007 & 0.005 & $6.45 \times 10^{-5}$ \\
\hline $\mathbf{H I}=\Sigma H_{Q_{i}}$ & 0.28 & $0.19 \times 10^{-2}$ & 0.032 & 0.043 & 0.006 \\
\hline Cancer risk & & & $0.144 \times 10^{-7}$ & $0.427 \times 10^{-6}$ & $9.41 \times 10^{-9}$ \\
\hline \multicolumn{6}{|l|}{ Adult } \\
\hline D $_{\text {ing }}$ & 0.0001 & $6.12 \times 10^{-5}$ & $2.72 \times 10^{-6}$ & $1.21 \times 10^{-5}$ & $1.33 \times 10^{-5}$ \\
\hline $\mathbf{D}_{\text {inh }}$ & $1.49 \times 10^{-8}$ & $0.9 \times 10^{-10}$ & $4.00 \times 10^{-10}$ & $1.78 \times 10^{-9}$ & $1.96 \times 10^{-9}$ \\
\hline Ddermal & $4.05 \times 10^{-6}$ & $2.44 \times 10^{-6}$ & $1.09 \times 10^{-7}$ & $4.84 \times 10^{-7}$ & $5.32 \times 10^{-7}$ \\
\hline LADD & & & $2.29 \times 10^{-9}$ & $10.17 \times 10^{-9}$ & 11.2 \\
\hline HQing & 0.029 & $0.2 \times 10^{-3}$ & 0.0027 & 0.004 & 0.0007 \\
\hline HQinh & $4.26 \times 10^{-7}$ & $3 \times 10^{-8}$ & $0.40 \times 10^{-8}$ & $6.23 \times 10^{-5}$ & $9.8 \times 10^{-8}$ \\
\hline HQdermal & 0.03 & $0.20 \times 10^{-3}$ & $0.27 \times 10^{-2}$ & $4.04 \times 10^{-2}$ & $0.67 \times 10^{-3}$ \\
\hline $\mathbf{H I}=\Sigma \mathrm{HQ}_{\mathbf{i}}$ & 0.037 & $0.24 \times 10^{-3}$ & 0.014 & 0.012 & $0.76 \times 10^{-3}$ \\
\hline Cancer risk & & & $0.144 \times 10^{-7}$ & $0.427 \times 10^{-6}$ & $9.41 \times 10^{-9}$ \\
\hline
\end{tabular}

Rfd: Specific reference dose; SF: Slope factor; D: Average daily dose; LADD: Lifetime average daily dose; HQ: Hazard quotient; HI: Hazard index

Table 5: Exposure dose, hazard quotient, and risk for each element and exposure pathway (mg/kg.day) in the green space

\begin{tabular}{|c|c|c|c|c|c|}
\hline & $\mathbf{P b}$ & Zn & Cd & $\mathrm{Cr}$ & $\mathbf{N i}$ \\
\hline RfD $_{\text {ing }}$ & $3.50 \times 10^{-3}$ & 0.30 & 0.001 & 0.003 & 0.02 \\
\hline RfD $_{\text {inh }}$ & $3.50 \times 10^{-2}$ & 0.30 & 0.001 & $0.286 \times 10^{-4}$ & 0.02 \\
\hline RfD dermal $_{\text {del }}$ & $5.25 \times 10^{-4}$ & 0.06 & $0.1 \times 10^{-4}$ & $0.06 \times 10^{-3}$ & $0.54 \times 10^{-2}$ \\
\hline $\mathbf{S f}_{\text {inh }}$ & & & 6.30 & 42 & 0.84 \\
\hline \multicolumn{6}{|l|}{ Child } \\
\hline $\mathbf{D}_{\text {ing }}$ & $0.797 \times 10^{-3}$ & $0.748 \times 10^{-3}$ & $3.06 \times 10^{-5}$ & $0.104 \times 10^{-3}$ & $0.1 \times 10^{-3}$ \\
\hline $\mathbf{D}_{\text {inh }}$ & $2.23 \times 10^{-8}$ & $2.09 \times 10^{-8}$ & $8.56 \times 10^{-10}$ & $2.91 \times 10^{-9}$ & $2.79 \times 10^{-9}$ \\
\hline$D_{\text {dermal }}$ & $2.23 \times 10^{-6}$ & $2.09 \times 10^{-6}$ & $8.58 \times 10^{-8}$ & $2.91 \times 10^{-7}$ & $2.8 \times 10^{-7}$ \\
\hline LADD & & & $2.76 \times 10^{-9}$ & $9.37 \times 10^{-9}$ & $0.9 \times 10^{-8}$ \\
\hline HQing & 0.228 & 0.002 & 0.03 & 0.035 & 0.005 \\
\hline HQinh & $6.36 \times 10^{-7}$ & $6.97 \times 10^{-8}$ & $8.56 \times 10^{-7}$ & 0.0001 & $1.397 \times 10^{-7}$ \\
\hline HQdermal & 0.004 & $3.492 \times 10^{-5}$ & 0.0086 & 0.0049 & $5.186 \times 10^{-5}$ \\
\hline $\mathbf{H I}=\Sigma \mathrm{HQ}_{\mathbf{i}}$ & 0.232 & 0.0025 & 0.039 & 0.039 & 0.005 \\
\hline Cancer risk & & & $1.74 \times 10^{-8}$ & $3.94 \times 10^{-7}$ & $7.56 \times 10^{-9}$ \\
\hline \multicolumn{6}{|l|}{ Adult } \\
\hline Ding $_{\text {in }}$ & $8.54 \times 10^{-5}$ & $8.02 \times 10^{-5}$ & $3.28 \times 10^{-6}$ & $1.12 \times 10^{-5}$ & $1.07 \times 10^{-5}$ \\
\hline $\mathbf{D}_{\text {inh }}$ & $1.26 \times 10^{-8}$ & $1.18 \times 10^{-8}$ & $4.83 \times 10^{-10}$ & $1.64 \times 10^{-9}$ & $1.58 \times 10^{-9}$ \\
\hline$D_{\text {dermal }}$ & $3.41 \times 10^{-6}$ & $3.2 \times 10^{-6}$ & $1.31 \times 10^{-7}$ & $4.45 \times 10^{-7}$ & $4.28 \times 10^{-7}$ \\
\hline LADD & & & $2.76 \times 10^{-9}$ & $9.37 \times 10^{-9}$ & $0.9 \times 10^{-8}$ \\
\hline HQing & 0.024 & 0.00027 & 0.0033 & 0.0037 & 0.00054 \\
\hline HQinh & $3.586 \times 10^{-7}$ & $3.93 \times 10^{-8}$ & $4.828 \times 10^{-7}$ & $5.734 \times 10^{-5}$ & $7.879 \times 10^{-8}$ \\
\hline $\mathbf{H Q}_{\text {dermal }}$ & 0.0065 & $5.331 \times 10^{-5}$ & 0.0131 & 0.0074 & $7.918 \times 10^{-5}$ \\
\hline $\mathbf{H I}=\Sigma \mathbf{H Q}_{\mathbf{i}}$ & 0.031 & 0.00032 & 0.016 & 0.011 & 0.0006 \\
\hline
\end{tabular}




\section{Cancer risk}

$1.74 \times 10^{-8}$

$3.94 \times 10^{-7}$

$7.56 \times 10^{-9}$

Rfd: Specific reference dose; SF: Slope factor; D: Average daily dose; LADD: Lifetime average daily dose; HQ: Hazard quotient; HI: Hazard index

Table 6: Exposure dose, hazard quotient, and risk for each element and exposure pathway (mg/kg.day) for the residential area

\begin{tabular}{|c|c|c|c|c|c|}
\hline & $\mathbf{P b}$ & Zn & Cd & $\mathrm{Cr}$ & $\mathbf{N i}$ \\
\hline RfDing $_{\text {ing }}$ & $3.50 \times 10^{-03}$ & 0.30 & 0.001 & 0.003 & 0.02 \\
\hline RfDinh & $3.50 \times 10^{-02}$ & 0.30 & 0.001 & $0.286 \times 10^{-4}$ & 0.02 \\
\hline RfD dermal $_{\text {d }}$ & $5.25 \times 10^{-04}$ & 0.06 & $0.1 \times 10^{-4}$ & $0.06^{-3}$ & $0.54 \times 10^{-2}$ \\
\hline Sfinh & & & 6.30 & 42 & 0.84 \\
\hline \multicolumn{6}{|l|}{ Child } \\
\hline$D_{\text {ing }}$ & $0.11 \times 10^{-2}$ & $0.82 \times 10^{-3}$ & $3.43 \times 10^{-5}$ & $0.11 \times 10^{-3}$ & $0.17 \times 10^{-3}$ \\
\hline D $_{\text {inh }}$ & $3.01 \times 10^{-8}$ & $2.29 \times 10^{-8}$ & $9.59 \times 10^{-10}$ & $3.01 \times 10^{-9}$ & $4.84 \times 10^{-9}$ \\
\hline D dermal & $3.02 \times 10^{-6}$ & $2.29 \times 10^{-6}$ & $9.61 \times 10^{-8}$ & $3.02 \times 10^{-7}$ & $4.85 \times 10^{-7}$ \\
\hline LADD & & & $3.09 \times 10^{-9}$ & $9.71 \times 10^{-9}$ & $1.56 \times 10^{-8}$ \\
\hline HQing & 0.308 & 0.0027 & 0.034 & 0.036 & 0.0087 \\
\hline HQinh & $8.601 \times 10^{-7}$ & $7.634 \times 10^{-8}$ & $9.590 \times 10^{-7}$ & $0.105 \times 10^{-3}$ & $2.419 \times 10^{-7}$ \\
\hline $\mathbf{H Q}_{\text {dermal }}$ & 0.0057 & $3.825 \times 10^{-5}$ & 0.0096 & 0.005 & $8.977 \times 10^{-5}$ \\
\hline$H I=\Sigma H Q_{i}$ & 0.031 & 0.003 & 0.044 & 0.041 & 0.009 \\
\hline Cancer risk & & & $1.94 \times 10^{-8}$ & $4.08 \times 10^{-7}$ & $1.31 \times 10^{-8}$ \\
\hline \multicolumn{6}{|l|}{ Adult } \\
\hline$D_{\text {ing }}$ & $0.12 \times 10^{-3}$ & $0.82 \times 10^{-3}$ & $3.43 \times 10^{-5}$ & $0.11 \times 10^{-3}$ & $0.17 \times 10^{-3}$ \\
\hline Dinh & $1.7 \times 10^{-8}$ & $1.29 \times 10^{-8}$ & $5.41 \times 10^{-10}$ & $1.7 \times 10^{-9}$ & $2.73 \times 10^{-9}$ \\
\hline $\mathbf{D}_{\text {dermal }}$ & $4.61 \times 10^{-6}$ & $3.5 \times 10^{-6}$ & $1.47 \times 10^{-7}$ & $4.61 \times 10^{-7}$ & $7.4 \times 10^{-7}$ \\
\hline LADD & & & $3.09 \times 10^{-9}$ & $9.71 \times 10^{-9}$ & $1.56 \times 10^{-8}$ \\
\hline HQing & 0.033 & $0.293 \times 10^{-3}$ & $0.368 \times 10^{-2}$ & $0.39 \times 10^{-2}$ & $0.927 \times 10^{-3}$ \\
\hline HQinh & $4.85 \times 10^{-7}$ & $4.305 \times 10^{-8}$ & $5.408 \times 10^{-7}$ & $5.941 \times 10^{-5}$ & $1.364 \times 10^{-7}$ \\
\hline HQdermal & $0.877 \times 10^{-2}$ & $0.84 \times 10^{-6}$ & 0.0147 & $0.77 \times 10^{-2}$ & $0137 \times 10^{-3}$ \\
\hline$H I=\Sigma H Q_{i}$ & 0.042 & 0.004 & 0.018 & 0.012 & 0.001 \\
\hline Cancer risk & & & $1.94 \times 10^{-8}$ & $4.08 \times 10^{-7}$ & $1.31 \times 10^{-8}$ \\
\hline
\end{tabular}

Rfd: Specific reference dose; SF: Slope factor; D: Average daily dose; LADD: Lifetime average daily dose; HQ: Hazard quotient; HI: Hazard index

\section{Residential}

The risk assessment results indicated that in residential use, the highest risk value was related to ingestion of $\mathrm{Pb}$ in children, whereas the highest risk value was related to ingestion of $\mathrm{Cd}$ in adults (Table 6).

Table 7: Exposure dose, hazard quotient, and risk for each element and exposure pathway ( $\mathrm{mg} / \mathrm{kg}$.day) in the under construction area

\begin{tabular}{|c|c|c|c|c|c|}
\hline & $\mathbf{P b}$ & $\mathbf{Z n}$ & Cd & $\mathrm{Cr}$ & $\mathbf{N i}$ \\
\hline RfD $_{\text {ing }}$ & $3.50 \times 10^{-03}$ & 0.30 & 0.001 & 0.003 & 0.02 \\
\hline RfD $_{\text {inh }}$ & $3.50 \times 10^{-02}$ & 0.30 & 0.001 & $0.286 \times 10^{-4}$ & 0.02 \\
\hline RfD dermal $_{\text {d }}$ & $5.25 \times 10^{-04}$ & 0.06 & $0.1 \times 10^{-4}$ & $0.06^{-3}$ & $0.54 \times 10^{-2}$ \\
\hline Sfinh & & & 6.30 & 42 & 0.84 \\
\hline \multicolumn{6}{|l|}{ Child } \\
\hline$D_{\text {ing }}$ & $0.11 \times 10^{-2}$ & $0.556 \times 10^{-3}$ & $2.93 \times 10^{-5}$ & $0.104 \times 10^{-3}$ & $0.148 \times 10^{-3}$ \\
\hline $\mathbf{D}_{\text {inh }}$ & $3.01 \times 10^{-8}$ & $1.55 \times 10^{-8}$ & $8.19 \times 10^{-10}$ & $2.92 \times 10^{-9}$ & $4.13 \times 10^{-9}$ \\
\hline Ddermal & $3.01 \times 10^{-6}$ & $1.56 \times 10^{-6}$ & $8.21 \times 10^{-8}$ & $2.93 \times 10^{-7}$ & $4.14 \times 10^{-7}$ \\
\hline LADD & & & $2.64 \times 10^{-9}$ & $9.41 \times 10^{-9}$ & $1.33 \times 10^{-8}$ \\
\hline HQ $_{\text {ing }}$ & 0.307 & $0.185 \times 10^{-2}$ & 0.029 & 0.0348 & 0.0074 \\
\hline HQinh & $8.588 \times 10^{-7}$ & $5.183 \times 10^{-8}$ & $8.1948 \times 10^{-7}$ & $0.102 \times 10^{-3}$ & $2.063 \times 10^{-7}$ \\
\hline HQdermal & $0.574 \times 10^{-2}$ & $2.597 \times 10^{-5}$ & $0.821 \times 10^{-2}$ & $0.488 \times 10^{-2}$ & $7.658 \times 10^{-5}$ \\
\hline $\mathbf{H I}=\Sigma H Q_{i}$ & 0.313 & 0.00188 & 0.0375 & 0.0399 & 0.00746 \\
\hline Cancer risk & & & $1.64 \times 10^{-8}$ & $3.95 \times 10^{-7}$ & $1.11 \times 10^{-8}$ \\
\hline \multicolumn{6}{|l|}{ Adult } \\
\hline D $_{\text {ing }}$ & $0.12 \times 10^{-3}$ & $0.596 \times 10^{-6}$ & $0.314 \times 10^{-6}$ & $0.112 \times 10^{-6}$ & $0.158 \times 10^{-6}$ \\
\hline $\mathbf{D}_{\text {inh }}$ & $1.7 \times 10^{-8}$ & $8.77 \times 10^{-9}$ & $4.62 \times 10^{-10}$ & $1.65 \times 10^{-9}$ & $2.33 \times 10^{-9}$ \\
\hline Ddermal & $4.60 \times 10^{-6}$ & $2.38 \times 10^{-6}$ & $1.25 \times 10^{-7}$ & $4.47 \times 10^{-7}$ & $6.31 \times 10^{-7}$ \\
\hline LADD & & & $2.64 \times 10^{-9}$ & $9.41 \times 10^{-9}$ & $1.33 \times 10^{-8}$ \\
\hline
\end{tabular}




\begin{tabular}{|c|c|c|c|c|c|}
\hline HQing & 0.033 & $0.199 \times 10^{-3}$ & $0.314 \times 10^{-2}$ & $0.37 \times 10^{-2}$ & $0.791 \times 10^{-3}$ \\
\hline HQinh & $4.84 \times 10^{-7}$ & $2.923 \times 10^{-8}$ & $4.621 \times 10^{-7}$ & $5.756 \times 10^{-5}$ & 1. $163 \times 10^{-7}$ \\
\hline HQdermal & $0.876 \times 10^{-2}$ & $3.965 \times 10^{-5}$ & 0.0125 & $0.744 \times 10^{-2}$ & $0.117 \times 10^{-3}$ \\
\hline$H I=\Sigma H Q_{i}$ & 0.0417 & $0.238 \times 10^{-3}$ & 0.0157 & 0.0112 & $0.908 \times 10^{-3}$ \\
\hline Cancer risk & & & $1.64 \times 10^{-8}$ & $3.95 \times 10^{-7}$ & $1.11 \times 10^{-8}$ \\
\hline
\end{tabular}

Rfd: Specific reference dose; SF: Slope factor; D: Average daily dose; LADD: Lifetime average daily dose; HQ: Hazard quotient; HI: Hazard index

\section{Under construction}

The results of risk assessment in under construction areas are presented in table 7, wherein the highest risk value is related to ingestion of $\mathrm{Pb}$.

\section{Natural use}

As demonstrated in table 8 and by the results of the used models, the non-carcinogenic health risks of children were higher than adults in natural areas.

Table 8: Exposure dose, hazard quotient, and risk for each element and exposure pathway (mg/kg.day) in natural areas

\begin{tabular}{|c|c|c|c|c|c|}
\hline & $\mathrm{Pb}$ & $\mathrm{Zn}$ & $\mathrm{Cd}$ & $\mathrm{Cr}$ & $\mathrm{Ni}$ \\
\hline $\mathrm{RfD}_{\text {ing }}$ & $3.50 \times 10^{-3}$ & 0.30 & 0.001 & 0.003 & 0.02 \\
\hline $\mathrm{RfD}_{\text {inh }}$ & $3.50 \times 10^{-02}$ & 0.30 & 0.001 & $0.286 \times 10^{-4}$ & 0.02 \\
\hline $\mathrm{RfD}_{\text {dermal }}$ & $5.25 \times 10^{-04}$ & 0.06 & $0.1 \times 10^{-4}$ & $0.06 \times 10^{-3}$ & $0.54 \times 10^{-2}$ \\
\hline $\mathrm{Sf}_{\text {inh }}$ & & & 6.30 & 42 & 0.84 \\
\hline \multicolumn{6}{|l|}{ Child } \\
\hline $\mathrm{D}_{\text {ing }}$ & $0.845 \times 10^{-3}$ & $0.105 \times 10^{-3}$ & $4.27 \times 10^{-6}$ & $0.142 \times 10^{-6}$ & $7.69 \times 10^{-5}$ \\
\hline $\mathrm{D}_{\text {inh }}$ & $2.36 \times 10^{-8}$ & $2.95 \times 10^{-9}$ & $1.19 \times 10^{-10}$ & $3.97 \times 10^{-9}$ & $2.15 \times 10^{-9}$ \\
\hline$D_{\text {dermal }}$ & $2.37 \times 10^{-6}$ & $2.95 \times 10^{-7}$ & $1.20 \times 10^{-8}$ & $3.98 \times 10^{-7}$ & $2.15 \times 10^{-7}$ \\
\hline LADD & & & $3.85 \times 10^{-10}$ & $1.28 \times 10^{-8}$ & $6.93 \times 10^{-9}$ \\
\hline $\mathrm{HQ}_{\text {ing }}$ & 0.241 & $0.352 \times 10^{-3}$ & $0.427 \times 10^{-2}$ & 0.0474 & $0.385 \times 10^{-2}$ \\
\hline $\mathrm{HQ}_{\text {inh }}$ & $6.74 \times 10^{-7}$ & $9.823 \times 10^{-9}$ & $1.194 \times 10^{-7}$ & $0.139 \times 10^{-3}$ & $1.075 \times 10^{-7}$ \\
\hline $\mathrm{HQ}_{\text {dermal }}$ & $0.45 \times 10^{-2}$ & $4.921 \times 10^{-6}$ & 0.0012 & $0.663 \times 10^{-2}$ & $3.99 \times 10^{-5}$ \\
\hline $\mathrm{HI}=\Sigma \mathrm{HQ}_{\mathrm{i}}$ & 0.246 & $0.356 \times 10^{-3}$ & 0.0055 & 0.054 & 0.0039 \\
\hline Cancer risk & & & $5.82 \times 10^{-9}$ & $5.37 \times 10^{-7}$ & $2.42 \times 10^{-9}$ \\
\hline \multicolumn{6}{|l|}{ Adult } \\
\hline $\mathrm{D}_{\text {ing }}$ & $9.05 \times 10^{-5}$ & $1.13 \times 10^{-5}$ & $4.58 \times 10^{-7}$ & $1.52 \times 10^{-5}$ & $8.24 \times 10^{-6}$ \\
\hline $\mathrm{D}_{\text {inh }}$ & $1.33 \times 10^{-8}$ & $1.66 \times 10^{-9}$ & $6.73 \times 10^{-11}$ & $2.24 \times 10^{-9}$ & $1.21 \times 10^{-9}$ \\
\hline$D_{\text {dermal }}$ & $3.61 \times 10^{-6}$ & $4.51 \times 10^{-7}$ & $1.83 \times 10^{-8}$ & $6.07 \times 10^{-7}$ & $3.29 \times 10^{-7}$ \\
\hline LADD & & & $3.85 \times 10^{-10}$ & $1.28 \times 10^{-8}$ & $6.93 \times 10^{-9}$ \\
\hline $\mathrm{HQ}_{\text {ing }}$ & 0.0259 & $3.767 \times 10^{-5}$ & $0.46 \times 10^{-3}$ & 0.0051 & $0.41 \times 10^{-3}$ \\
\hline $\mathrm{HQ}_{\text {inh }}$ & $3.802 \times 10^{-7}$ & $5.539 \times 10^{-9}$ & $6.734 \times 10^{-8}$ & $7.828 \times 10^{-5}$ & $6.061 \times 10^{-8}$ \\
\hline $\mathrm{HQ}_{\text {dermal }}$ & 0.0069 & $0.751 \times 10^{-5}$ & 0.0018 & 0.0101 & $0.609 \times 10^{-4}$ \\
\hline $\mathrm{HI}=\Sigma \mathrm{HQ}_{\mathrm{i}}$ & 0.0327 & $0.452 \times 10^{-4}$ & 0.0023 & 0.0153 & $0.47 \times 10^{-3}$ \\
\hline Cancer risk & & & $5.82 \times 10^{-9}$ & $5.37 \times 10^{-7}$ & $2.42 \times 10^{-9}$ \\
\hline
\end{tabular}

Rfd: Specific reference dose; SF: Slope factor; D: Average daily dose; LADD: Lifetime average daily dose; HQ: Hazard quotient; HI: Hazard index

\section{Discussion}

The mean concentrations of $\mathrm{Pb}(144 \pm 89.90$ $\mathrm{mg} / \mathrm{kg})$ and $\mathrm{Cd}(3.86 \pm 2.02 \mathrm{mg} / \mathrm{kg})$ were considerably higher than the background level $(100 \mathrm{mg} / \mathrm{kg}$ for $\mathrm{Pb})(0.8 \mathrm{mg} / \mathrm{kg}$ for $\mathrm{Cd})(22)$. The mean concentrations of these heavy metals obtained by other researchers in Tehran were also higher than background level. Saeedi et al. reported the mean concentrations of $\mathrm{Pb}, \mathrm{Zn}, \mathrm{Ni}$, and $\mathrm{Cd}$ in roadside soil of Tehran-Karaj Highway, Iran as $669.30 \mathrm{mg} / \mathrm{kg}, 614.312 \mathrm{mg} / \mathrm{kg}$,
$90.32 \mathrm{mg} / \mathrm{kg}$, and $3.90 \mathrm{mg} / \mathrm{kg}$, respectively (15). The HQs of children through ingestion were averaged 7.5 times higher in comparison to adults. Outputs of the model indicated that the order of the major exposure routes to street dust for both adults and children were ingestion > dermal contact $>$ inhalation. Ingestion is the major route of exposure to street dust for both adults and children. The potential health risk through inhalation is almost negligible as compared to other exposure routes. Similar 
results were obtained by $\mathrm{Wu}$ et al., who performed health risk assessment of heavy metals in Dongguan, China (9). Moreover, Zheng et al. (23) studied exposure to heavy metals in street dust in a zinc smelting district and Fang et al. (24) investigated exposure to heavy metals in surface dust of the Wuhu urban area, China. The order of non-cancerous HIs of metals were $\mathrm{Pb}>\mathrm{Cr}>\mathrm{Cd}>\mathrm{Zn}$ for children and $\mathrm{Pb}>\mathrm{Cr}>\mathrm{Cd}>\mathrm{Ni}>\mathrm{Zn}$ for adults, indicating similar highest and lowest HIs of metals. $\mathrm{Pb}$ depicted the highest risk value (0.28), whereas $\mathrm{Zn}$ indicated the lowest risk value (0.0019). Similarly, Olawoyin et al. reported the maximum total risk for $\mathrm{Pb}$ as 2.6E-02. Furthermore, Keshavarzi et al. showed HI level in the order of $\mathrm{Pb}>\mathrm{Hg}>\mathrm{Cu}>\mathrm{Zn}>\mathrm{Ni}>\mathrm{Mn}>$ $\mathrm{Sb}>\mathrm{Cr}>\mathrm{Fe}$, wherein $\mathrm{Pb}$ had the highest risk value (0.223), and $\mathrm{Fe}$ exhibited the lowest value (0.00012). The HQs for children averaged 2.57.5 times higher than adults, especially for $\mathrm{Zn}$, $\mathrm{Pb}$, and Ni. The HQs and HIs for all heavy metals were lower than 1 , indicating that the adverse health impact on children and adults exposed to heavy metals in road dust was relatively low in Tehran city (12).

Some heavy metals (for example $\mathrm{Pb}$ ) have a cumulative effect (25). It has been reported that elements such as $\mathrm{Zn}, \mathrm{Pb}$, and $\mathrm{Ni}$ in the environment have a major influence on children's health. Considering the higher ingestion rate for children, the exposure of children to soil may exhibit higher potential health risks. Among the carcinogenic metals, $\mathrm{Cd}, \mathrm{Cr}$, and $\mathrm{Ni}$ were analyzed. The carcinogenic risk levels of these metals were $<10^{-6}$ with higher values attributed to $\mathrm{Cr}\left(0.427 \times 10^{-6}\right)$, followed by $\mathrm{Cd}\left(0.144 \times 10^{-7}\right)$ and $\mathrm{Ni}\left(9.41 \times 10^{-}\right.$ $\left.{ }^{9}\right)$. Thus, the carcinogenic risks of these three studied metals were lower than the threshold values range $\left(10^{-6}-10^{-4}\right)$, above which environmental and regulatory agencies consider the risk unacceptable; therefore, it can be safely suggested that there was no cancer risk in Tehran city $(9,3,12,14)$.

The non-carcinogenic health risk for children was higher than that for adults. The risk assessment results showed that the highest risk value pertained to ingestion of $\mathrm{Pb}$. In the green space, $\mathrm{HI}$ values decreased in the order of $\mathrm{Pb}>$ $\mathrm{Cr}>\mathrm{Cd}>\mathrm{Ni}>\mathrm{Zn}$ for both children and adults; $\mathrm{Pb}$ exhibited the highest risk value, whereas $\mathrm{Zn}$ indicated the lowest risk value. The HQs for children averaged 2.3-8.2 times higher than adults. The HQs and HIs for all heavy metals were lower than 1 , which indicated that the adverse health impact on children and adults exposed to heavy metals in road dust was relatively low in Tehran city. Among the carcinogenic metals, $\mathrm{Cd}, \mathrm{Cr}$, and $\mathrm{Ni}$ were analyzed for the said land use (green space). The carcinogenic risks for the studied metals were lower than the threshold values range $\left(10^{-6}-10^{-4}\right)$. In residential use, $\mathrm{HI}$ values decreased in the order of $\mathrm{Cd}>\mathrm{Cr}>\mathrm{Pb}>\mathrm{Ni}>\mathrm{Zn}$ for children, and in the order of $\mathrm{Pb}>\mathrm{Cd}>\mathrm{Cr}>\mathrm{Zn}>\mathrm{Ni}$ for adults; $\mathrm{Pb}$ demonstrated the highest risk value for adults whereas for children $\mathrm{Cd}$ presented the highest risk value. Nevertheless, in children, HQs averaged 2.3-8.2 times higher than adults. The HQs and HIs for all heavy metals were lower than 1 in residential use. The carcinogenic risks for metals viz. $\mathrm{Cd}\left(1.94 \times 10^{-8}\right), \mathrm{Cr}(4.08 \times$ $\left.10^{-7}\right)$, and $\mathrm{Ni}\left(1.31 \times 10^{-8}\right)$ were lower than the threshold values range $\left(10^{-6}-10^{-4}\right)$. Likewise, Olawoyin et al. reported that soil contamination in the industrial and residential regions are similarly significant (14). However, the risk assessment proved that, based on the concentration of pollutants in the soil, metals with the highest cancer risk values $(\mathrm{Pb}=2.62 \times$ $10^{-2}$ and $\operatorname{Cr}(\mathrm{VI})=1.52 \times 10^{-2}$ ) have the potential to affect the health status of residents, especially children. The chronic daily intake of metals is of major concern as their cumulative effect could result to numerous health complications in children and adults in the region.

The results of risk assessment in under construction areas are shown in table 7 , wherein the highest risk value pertained to $\mathrm{Pb}$ ingestion. In under construction use, HI values decreased in the order of $\mathrm{Pb}>\mathrm{Cr}>\mathrm{Cd}>\mathrm{Ni}>\mathrm{Zn}$ for children, and in the order of $\mathrm{Pb}>\mathrm{Cd}>\mathrm{Cr}>\mathrm{Ni}$ $>\mathrm{Zn}$ for adults. $\mathrm{Pb}$ demonstrated the highest risk value, whereas $\mathrm{Zn}$ indicated the lowest value in both age groups. The HQs for children averaged 
2.3-8.2 times higher than adults. The HQs and HIs for all heavy metals were lower than 1, which indicated that the adverse health impact on children and adults exposed to heavy metals in road dust was relatively low in under construction areas. Moreover, the carcinogenic risks for $\mathrm{Cd}\left(1.64 \times 10^{-8}\right), \mathrm{Cr}\left(3.95 \times 10^{-7}\right)$, and Ni $\left(1.11 \times 10^{-8}\right)$ were lower than the threshold values range $\left(10^{-6}-10^{-4}\right)$.

As indicated in table 9, for natural use, the noncarcinogenic health risk for children was higher than adults. The results of risk assessment exhibited that the highest risk value was related to ingestion of $\mathrm{Pb}$. The order of non-cancerous HIs of metals in natural use was $\mathrm{Pb}>\mathrm{Cr}>\mathrm{Cd}>$ $\mathrm{Ni}>\mathrm{Zn}$ in both children and adults. $\mathrm{Pb}(0.313)$ exhibited the highest risk value, whereas $\mathrm{Zn}$ (0.002) showed the lowest risk value. The HQs for children averaged 2.3-8.2 times higher than adults. The HQs and HIs for all heavy metals were lower than 1 . The carcinogenic risk levels of these metals were $<10^{-6}$, with higher values attributed to $\mathrm{Cr}\left(5.37 \times 10^{-7}\right)$, followed by $\mathrm{Cd}$ $\left(5.82 \times 10^{-9}\right)$, and $\mathrm{Ni}\left(2.42 \times 10^{-9}\right)$. Thus, the carcinogenic risks for these three metals were lower than the threshold values range $\left(10^{-6}-10^{-4}\right)$, above which environmental and regulatory agencies consider the risk unacceptable, this signifies no cancer risk for natural use in Tehran city. Junhua et al. collected surface dust samples from 14 different sites in 5 different function areas in Maha Sarakham and Thailand municipality (7). Function areas were classified as commercial, parking lot, residential, park, and traffic. The order of non-cancerous HIs of metals was $\mathrm{Cd}>\mathrm{Pb}>\mathrm{Cu}>\mathrm{Zn}$ for children and $\mathrm{Pb}>\mathrm{Cd}>\mathrm{Cu}>\mathrm{Zn}$ for adults. The HQs and HIs for all heavy metals were lower than 1 , which indicated adverse health effects on children and adults exposed to heavy metals. However, surface dust was relatively light in Maha Sarakham city, and in terms of $\mathrm{Cd}$, there was no cancer risk in Maha Sarakham city.

\section{Conclusion}

The non-cancerous risk was calculated for different land uses, and both adults and children.
The results of risk assessment showed that the highest risk value was related to ingestion of $\mathrm{Pb}$. In all the selected land uses (green space, residential area, under construction, and natural), the non-carcinogenic health risk for children was higher than adults. However, the exception was in the case of residential area, wherein non-carcinogenic health risks of $\mathrm{Zn}$ in adults were higher than children. For children and adults, $\mathrm{HI}$ values decreased in the order of $\mathrm{Pb}>\mathrm{Cr}>\mathrm{Cd}>\mathrm{Ni}>\mathrm{Zn}$ in green space and natural use areas. In the residential area, $\mathrm{HI}$ values decreased in the order of $\mathrm{Pb}>\mathrm{Cd}>\mathrm{Cr}>$ $\mathrm{Ni}>\mathrm{Zn}$ for both children and adults. As indicated, non-carcinogenic risks of $\mathrm{Cd}$ were higher than $\mathrm{Cr}$ and health risk of $\mathrm{Cd}$ increased in the residential area.

A noteworthy observation in this study was that the risk of non-carcinogenic metals was slightly different in the two groups, and $\mathrm{HI}$ values decreased in the order of $\mathrm{Pb}>\mathrm{Cr}>\mathrm{Cd}>\mathrm{Ni}>$ $\mathrm{Zn}$ for children, and $\mathrm{Pb}>\mathrm{Cd}>\mathrm{Cr}>\mathrm{Ni}>\mathrm{Zn}$ for adults. Thus, it can be safely concluded that $\mathrm{Pb}$ had the highest non-carcinogenic risk value and $\mathrm{Zn}$ had the lowest non-carcinogenic risk value. Regarding land use, only the non-carcinogenic risks of $\mathrm{Cd}$ and $\mathrm{Cr}$ changed. Among the carcinogenic metals, $\mathrm{Cd}, \mathrm{Cr}$, and $\mathrm{Ni}$ were analyzed for the land uses of green space, residential area, under construction, and natural. The carcinogenic risks of the studied metals were lower than the threshold values range $\left(10^{-}\right.$ $\left.{ }^{6}-10^{-4}\right)$, which signifies nil cancer risk in Tehran city.

\section{Acknowledgments}

The authors are grateful to the authorities of the Islamic Azad University, Science and Research Branch, for their assistance in and funds for this research. The authors also appreciate their useful feedback.

Conflict of Interest: None declared

\section{References}

1. Guitao Sh, Zhenlou Ch, Chunjuan B, Li W, Jiyan $\mathrm{T}$, Yuansheng L, et al. A comparative study of 
health risk of potentially toxic metals in urban and suburban road dust in the most populated city of China. Atmos Environ 2011; 45(3):764-71.

2. Chen $\mathrm{H}$, Teng $\mathrm{Y}$, Lu S, Wang Y, Wang J. Contamination features and health risk of soil heavy metals in China. Sci Total Environ 2015; 512-513:143-53.

3. Junhua M, Singhirunnusorn W. Distribution and health risk assessment of heavy metals in surface dusts of Maha Sarakham Municipality. Procedia Soc Behav Sci 2012; 50:280-93.

4. Liu X, Song Q, Tang Y, Li W, Xu J, Wu J, et al. Human health risk assessment of heavy metals in soil-vegetable system: a multi-medium analysis. Sci Total Environ 2013; 463-464:530-40.

5. Khan K, Lu Y, Khan H, Ishtiaq M, Khan S, Waqas $M$, et al. Heavy metals in agricultural soils and crops and their health risks in Swat District, northern Pakistan. Food Chem Toxicol 2013; 58:449-58.

6. Shah MT, Begum Sh, Khan S. Pedo and biogeochemical studies of mafic and ultramafic rocks in the Mingora and Kabal areas, Swat, Pakistan. Environ Earth Sci 2010; 60(5):10911102.

7. Sayadi MH, Rezaei MR, Rezaei A. Sediment toxicity and ecological risk of trace metals from streams surrounding a municipal solid waste landfill. Bull Environ Contam Toxicol 2015; 94(5):559-63.

8. Yasir F, Tufail M, Tayyeb Javed M, Chaudhry $\mathrm{MM}$, Siddique N .Road dust pollution of $\mathrm{Cd}, \mathrm{Cu}$, $\mathrm{Ni}, \mathrm{Pb}$ and $\mathrm{Zn}$ along Islamabad Expressway, Pakistan. Microchem J 2009; 92(2):186-92.

9. Wu S, Peng S, Zhang X, Wu D, Luo W, Zhang $\mathrm{T}$, et al. Levels and health risk assessments of heavy metals in urban soils in Dongguan, China. J Geochem Explor 2015; 148:71-8.

10. Sayadi MH, Shabani M, Ahmadpour N. Pollution index and ecological risk of heavy metals in the surface soils of Amir-Abad area in Birjand city, Iran. Health Scope 2015; 4(1):ee21137, doi:10.17795/jhealthscope-21137

11. Mielke HW, Gonzales Ch, Smith MK, Mielke PW. The urban environment and children's health: Soil as an integrator of lead, zinc, and cadmium in New Orleans, Louisiana, USA. Environ Res 1999; 81(2):117-29.

12. Keshavarzi B, Tazarvi Z, Rajabzadeh MA, Najmeddin A. Chemical speciation, human health risk assessment and pollution level of selected heavy metals in urban street dust of Shiraz, Iran. Atmos Environ 2015; 119:1-10.

13. Sayadi MH, Rezaei MR. Impact of land use on the distribution of toxic metals in surface soils in Birjand city, Iran. International Academy of Ecology and Environmental Sciences 2014; 4(1):18-29.

14. Olawoyin R, Oyewole SA, Grayson RL. Potential risk effect from elevated levels of soil heavy metals on human health in the Niger delta. Ecotoxicol Environ Saf 2012; 85:120-30.

15. Saeedi M, Hosseinzadeh M, Jamshidi A, Pajooheshfar SP. Assessment of heavy metals contamination and leaching characteristics in highway side soils, Iran. Environ. Monit Assess 2009; 151(1):231-41.

16. Gholampour A, Nabizadeh R, Naseri S, Yunesian M, Taghipour H, Rastkari N, et al. Exposure and health impacts of outdoor particulate matter in two urban and industrialized area of Tabriz, Iran. J Environ Health Sci Eng 2014; 12:27-37.

17. U.S.EPA. Exposure factors handbook 2011 edition (final). National Center for Environmental Assessment, Office of Research and Development, U.S. Environmental Protection Agency, Washington, DC; 2011 Sep. Report No.: EPA/600/R-09/052F,2011.

18. Blume HP. Page AL, Miller RH, Keeney DR (ed., 1982): Methods of soil analysis; 2. Chemical and microbiological properties, 2. Aufl. 1184 S., American Soc. of Agronomy (Publ.), Madison, Wisconsin, USA. J Plant Nutr Soil Sci 1985; 148(3):363-4.

19. U.S. The Risk Assessment Information System (RAIS) U.S. Dept. of Energy's Oak Ridge Operations Office (ORO); Oak Ridge, TN, USA: 2011.

20. U.S.EPA. Risk assessment guidance for superfund, Vol I: Human health evaluation manual, (Part E; Supplemental guidance for dermal risk assessment) final. Office of Superfund Remediation and Technology Innovation, U.S. Environmental Protection Agency, Washington, DC; 2004 July. Report No.: EPA/540/R/99/005

21. Shi G, Chen Z, Bi Ch, Wang L,Teng J, Li Y, et al. A comparative study of health risk of potentially toxic metals in urban and suburban road dust in the most populated city of China. Atmos Environ 2011; 45(3):764-71.

22. Sayadi MH, Sayyed MRG, Saptarshi PG .An assessment of the Chitgar River sediments for the short-term accumulation of the heavy metals from Tehran, Iran. Pollution Research 2008; 27(4):627-34.

23. Zhang M, Wang H. Concentrations and chemical forms of potentially toxic metals in roaddeposited sediments from different zones of Hangzhou, China. J Environ Sci 2009; 21(5):62531.

24. Fang F, Jiang B, Wang H, Xie H. Particle size distribution and health risk assessment of heavy metals in surface dust of Wuhu urban area. Geographical Research 2010; 29(7):1193-1202.

25. Sayadi MH, Torabi S. Geochemistry of soil and human health: A review. Pollution Research 2009; 28(2):257-62. 